\title{
BEBERAPA ASPEK BIOLOGI TERIPANG DI PERAIRAN KEPULAUAN SERIBU
}

\author{
Sri Turni Hartati", Suprapto", Indar Sri Wahyuni," dan Rusmawati Zainy")
}

\begin{abstract}
ABSTRAK
Penelitian tentang aspek biologi teripang di perairan Pulau Tikus dan Pulau Pramuka, Kepulauan Seribu telah dilakukan pada musim peralihan barat ke timur (Maret-Mei), musim timur (Juni-Agustus) dan musim peralihan timur ke barat (September-November) tahun 2001. Tujuan penelitian adalah untuk mengetahui beberapa aspek biologi teripang, seperti reproduksi, kebiasaan makan, dan pola pertumbuhan. Hasil analisis tingkat kematangan gonad menunjukkan bahwa musim pemijahan teripang di perairan Kepulauan Seribu berlangsung pada musim barat (Desember-Februari). Fitoplankton adalah makanan utama teripang dengan indek preponderasi lebih dari $50 \%$. Pada umumnya teripang di perairan Kepulauan Seribu mempunyai pola pertumbuhan allometrik negatif.
\end{abstract}

ABSTRACT Some biological aspects of sea cucumber in Seribu Islands Waters. By : Sri Turni Hartati, Suprapto, Indar Sri Wahyunl, and Rusmawati Zainy.

Observations on some biological aspects of sea cucumber in Tikus Isiand and Pramuka Island waters, Seribu Islands were done in transitional monsoon west to east, east monsoon and transitional monsoon east to west 2001. The aims of the obsenvation were to know some biological aspects of the sea cucumber, such: reproduction, feeding habits and growth pattem. The spawning season of the sea cucumber took place during west monsoon (December-February), the main food was phytoplankton with the index of preponderance more than $50 \%$. Generally, growth pattern of sea cucumber was allometric negative.

\section{KEYWORDS : biological aspects, sea cucumber, Seribu Islands}

\section{PENDAHULUAN}

Teripang adalah kelompok binatang laut yang mempunyai bentuk dan warna tubuh sangat menarik dan menjadi salah satu komoditas perikanan laut yang bernilai ekonomis tinggi. $\mathrm{Di}$ dalam taksonomi, teripang merupakan kelompok dari filum Echinodermata dan kelas Holothuroidea (Lawrence, 1987). Bentuk tubuh teripang adalah bulat panjang (elongated cylindrical) di sepanjang sumbu oral-aboral, yaitu sumbu yang menghubungkan bagian anterior dan posterior. Mulut dan anus terletak pada ujung poros yang berlawanan, yaitu mulut pada bagian anterior dan anus pada bagian posterior. Mulut teripang dikelilingi oleh sejumlah tentakel yang dapat dijulurkan dan ditarik kembali dengan cepat. Tentakel-tentakel ini merupakan modifikasi dari kaki tabung yang berfungsi untuk menangkap makanan (Storer et al., 1979). Warna teripang bermacam-macam, yaitu putih, hitam, coklat, kehijauan, kuning, abu-abu, jingga, ungu bahkan dengan pola bergaris (Ruppert dan Barnes, 1994).

Habitat atau tempat hidup teripang adalah ekosistem terumbu karang dan ekosistem lamun, mulai dari zona intertidal sampai kedalaman 20 meter. Pada umumnya teripang menyukai perairan yang jernih dengan salinitas normal sekitar 30-33 ppt, dasar berpasir halus dengan tanaman yang dapat melindungi secara langsung dari panas matahari seperti lamun dan rumput laut (Enhalus, Sargasum, Laminaria) dan terlindung dari arus yang kuat (Aziz, 1999).

Pasaran utama teripang adalah untuk ekspor. Seiring dengan meningkatnya permintaan dan harga teripang di pasaran ekspor, meningkat pula tekanan penangkapannya yang selanjutnya berakibat makin menurunnya stok teripang di alam. Oleh karena itu diperlukan upaya pengelolaan yang lestari terhadap sumber daya teripang. Penelitian aspek biologi perlu dilakukan untuk mendasari pengelolaan biota tersebut.

Tulisan ini menyajikan beberapa aspek biologi teripang, seperti reproduksi kebiasaan makan, dan pola pertumbuhan .

\section{BAHAN DAN METODE}

Penelitian dilakukan di perairan P.Tikus dan P.Pramuka pada musim peralihan barat ke timur (Maret-Mei), musim timur (Juni-Agustus) dan

\footnotetext{
Teneliti pada Balai Penelitlan Perlkanan Laut
} 
musim peralihan timur ke barat (SeptemberNovember) tahun 2001. Pulau Pramuka terletak dalam zona pemanfaatan tradisional kawasan Taman Nasional Laut Kepulauan Seribu pada

posisi $\quad 5^{\circ} 44^{\prime}-5^{\circ} 45^{\prime \prime} S$ dan $106^{\circ} 36^{\prime}-106^{\circ} 37^{\prime} \mathrm{E}$, sedangkan P.Tikus terletak dalam zona penyangga pada posisi $5^{\circ} 51^{\prime} \mathrm{S}$ dan $106^{\circ} 34^{\prime} \mathrm{E}$ (Gambar 1).

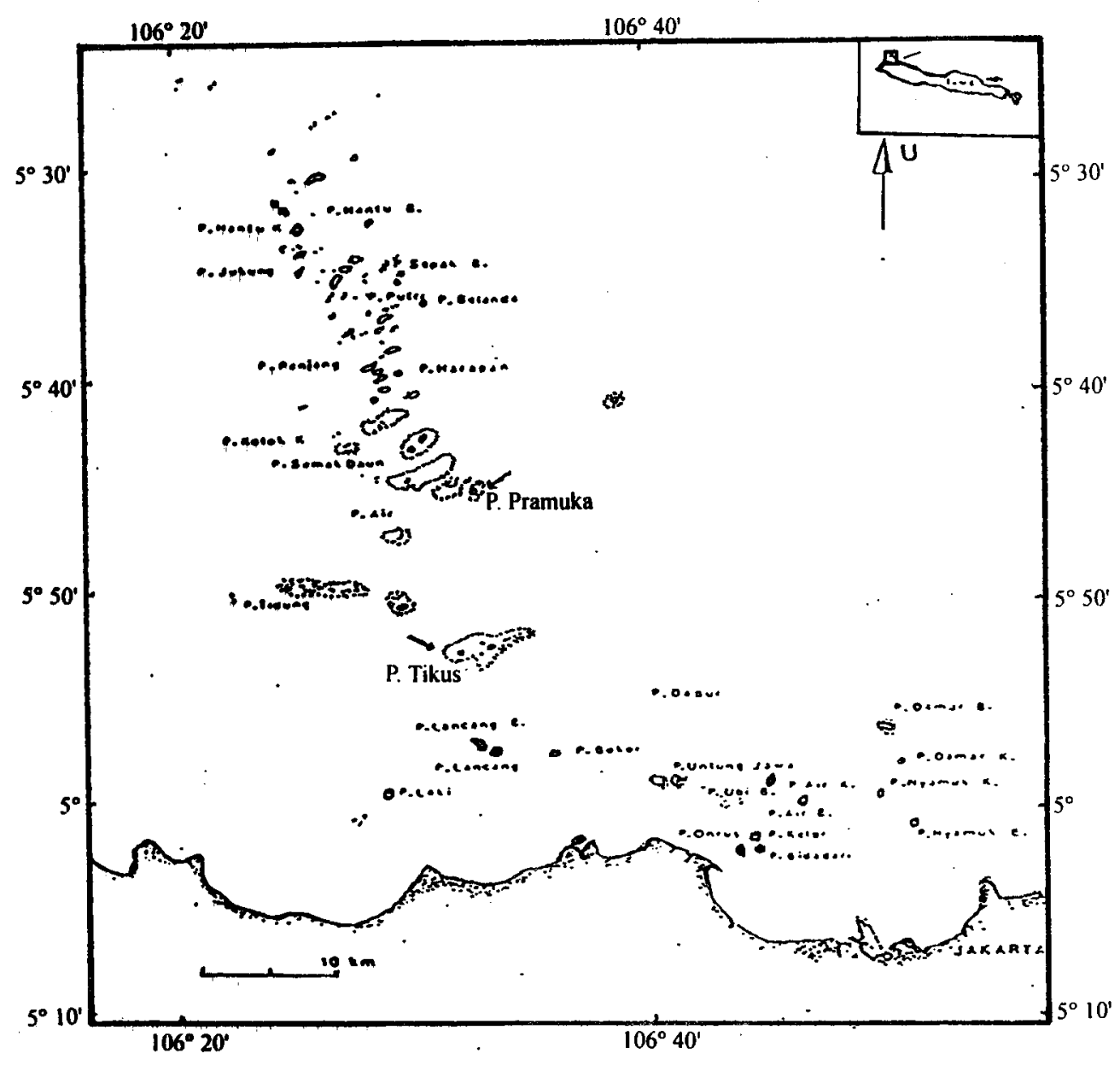

Gambar 1. Peta yang menunjukkan lokasi penelitian

Figure 1. Map showing the reseach locations

\section{Pengumpulan Data}

Pengumpulan data dilakukan masing-masing untuk keperluan reproduksi, kebiasaan makanan dan pertumbuhan.

\section{Reproduksi}

Aspek reproduksi yang diamati adalah tingkat kematangan gonad (TKG). Teripang yang digunakan sebagai sampel diambil secara acak dari hasil transek untuk pendugaan kepadatan stok. Teripang yang diamati meliputi jenis yang dominan yaitu Bohadschia marmorata (teripang olok-olok). Holothuria impatiens (teripang oler), Synapta maculata (teripang sabuk raja) dan yang bernilai ekonomis tinggi Stichopus variegatus (teripang gama). Jumlah per jenis teripang yang akan ditentukan tingkat kematangan gonadnya minimal 10 ekor, kecuali Stichopus variegatus (teripang gama) karena hasil transek tidak mencapai 10 ekor. Penentuan tingkat kematangan gonad mengacu pada Jiaxin (1990), yang membedakan atas lima fase reproduksi, yaitu fase pengosongan, perkembangan, pengaktifan, pematangan, dan pemijahan yang diuraikan pada Tabel 1

\section{Kebiasaan Makan}

Teripang yang digunakan sebagai sampel untuk analisis makanan terdiri atas 12 jenis, yaitu Actinopyga miliaris (teripang lotong), Bohadschia marmorata (teripang olok-olok), B. similis, 
Tabel 1. Penentuan tingkat kematangan gonad teripang menurut Jiaxin (1990)

Table 1. Determination of maturing stage for sea cucumber by Jiaxin (1990)

\begin{tabular}{|c|c|c|}
\hline $\begin{array}{l}\text { Stadia } \\
\text { (Stadium) }\end{array}$ & $\begin{array}{l}\text { Fase } \\
\text { (Phase) } \\
\end{array}$ & $\begin{array}{l}\text { Keterangan } \\
\text { (Remark) }\end{array}$ \\
\hline 1 & Pengosongan & Bobot gonad $\pm 0.6 \mathrm{gr}, \mathrm{IKG}<1 \%$ \\
\hline II & Perkembangan & Bobot gonad $\pm 2 \mathrm{gr}, \mathrm{IKG}<1 \%$, diameter oosit $\pm 40 \mu \mathrm{m}$ \\
\hline \multirow[t]{2}{*}{ III } & Pengaktifan 1 & Bobot gonad 2-59 gr, berwarna kuning/orange, IKG 1-3\%. \\
\hline & Pengaktifan 2 & $\begin{array}{l}\text { Bobot gonad } 3-13 \mathrm{gr} \text {, IKG } 7 \% \text {, diameter oosit } 60-90 \mu \mathrm{m} \text {, sperma mulai } \\
\text { terbentuk pada yang jantan. }\end{array}$ \\
\hline IV & Pematangan & Bobot gonad $>10 \mathrm{gr}$, IKG $10 \%$, diameter oosit $\pm 120 \mu \mathrm{m}$ \\
\hline V & Pemijahan & Bobot gonad $>10 \mathrm{gr}, \mathrm{IKG}>10 \%$, diameter oosit $150-170 \mu \mathrm{m}$ \\
\hline
\end{tabular}

Holothuria atra (teripang keling), H.hilla, $H$. coronopertusa, $H$. fuscupunctata, H.edulis (teripang dan merah), H.impatiens (teripang oler), $H$. nobilis (teripang susuan), Stichopus variegatus (teripang gama) dan Synapta maculata (teripang sabuk raja). Seperti pada pengumpulan data untuk aspek reproduksi, teripang yang digunakan sebagai sampel untuk pengamatan kebiasaan makan juga berasal dari hasil transek untuk pendugaan kepadatan stok.

\section{Pola Pertumbuhan}

Untuk mengetahui pola pertumbuhan teripang dilakukan analisis hubungan panjang dan bobot dengan menggunakan rumus (Hile, 1936 dalam Effendie, 1997) sebagai berikut :

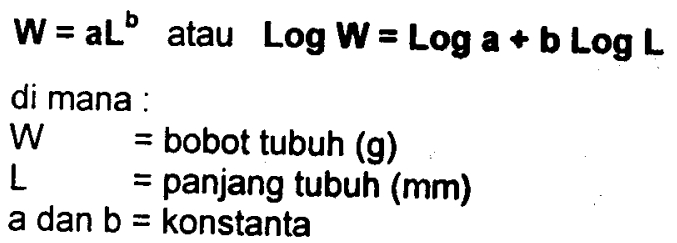

Jenis teripang yang diamati adalah Synapta maculata (teripang sabuk raja), Holothuria hilla dan Stichopus variegatus (teripang gama). Sampel teripang berasal dari hasil transek untuk pendugaan kepadatan stok. Kisaran panjang dan bobot beberapa jenis teripang yang digunakan untuk analisis aspek biologi disajikan pada Tabel 15.

\section{HASIL DAN BAHASAN}

\section{Reproduksi}

Hasil pengamatan menunjukkan bahwa pada musim peralihan barat ke timur tingkat kematangan gonad teripang didominasi oleh stadium II (fase perkembangan) sebanyak 68\%, pada musim timur didominasi oleh stadium III (fase peralihan) sebanyak $40 \%$ dan pada musim peralihan timur ke barat didominasi oleh stadium IV (fase pematangan) sebanyak $61 \%$. Selama pengamatan tidak dijumpai teripang dalam kondisi stadia V (fase pemijahan ). Kondisi tingkat kematangan gonad teripang disajikan pada Tabel 2. Pemijahan teripang biasanya berlangsung pada saat musim penghujan, karena pada musim tersebut terjadi penurunan salinitas yang meyebabkan perangsangan untuk matang gonad dan pemijahan (Alwi, 1995). Menurut Misnawati (1998) beberapa jenis teripang mengalami pemijahan dua kali dalam setahun yaitu pada sekitar bulan April dan bulan November. Dari hasil pengamatan tingkat kematangan gonad terhadap teripang Bohadschia marmorata, Holothuria impatiens, Synapta maculata dan Stichopus variegatus dapat diduga bahwa pada umumya musim pemijahan teripang di perairan Kepulauan Seribu berlangsung pada musim barat (DesemberFebruari).

\section{Kebiasaan Makan}

Teripang bersifat noctural yaitu kebiasaan mencari makanannya dilakukan pada malam hari. Teripang memperoleh makanan dengan cara menghisap dan menyaring makanan yang berada di perairan sekitarnya, seperti plankton dan detritus yang menempel pada substrat (Hyman, 1955). Kebiasaan teripang mencari makanan pada malam hari karena plankton akan berada di dasar perairan dan juga untuk menghindari predator. Kebiasaan makan tersebut memudahkan usaha penangkapan juga dilakukan pada malam hari, karena pada siang hari biasanya teripang akan terbenam dalam pasir atau masuk dalam terumbu karang. Analisis 
Tabel 2. Kondisi TKG teripang di perairan Kepulauan Seribu pada tahun 2001

Table 2. Maturing stages of the sea cucumber of Seribu Islands in 2001

\begin{tabular}{|c|c|c|c|c|c|c|}
\hline \multirow{2}{*}{ Stadia/Fase } & \multicolumn{2}{|c|}{$\begin{array}{c}\text { Peralihan } 1 \\
\text { (Transitional 1) }\end{array}$} & \multicolumn{2}{|c|}{$\begin{array}{l}\text { Timur } \\
\text { (East) }\end{array}$} & \multicolumn{2}{|c|}{$\begin{array}{c}\text { Peralihan } 2 \\
\text { (Transitional 2) }\end{array}$} \\
\hline & $n$ & $\%$ & $\mathrm{~N}$ & $\%$ & $\mathrm{~N}$ & $\%$ \\
\hline I. Pengosongan & 14 & 26 & 9 & 20 & - & - \\
\hline II. Perkembangan & 37 & 68 & 12 & 27 & 4 & 8 \\
\hline III. Pengaktifan & 4 & 6 & 18 & 40 & 14 & 31 \\
\hline IV. Pematangan & - & - & 6 & 13 & 28 & 61 \\
\hline V Pemijahan & - & $\ldots$ & - & - & - & - \\
\hline Jumlah/Total & 55 & 100 & 45 & 100 & 46 & 100 \\
\hline
\end{tabular}

Keterangan/Remarks : $n$ = jumlah teripang yang diamati / numbers of cucumber sea were observed

makanan yang dilakukan pada 12 jenis teripang menunjukkan bahwa fitoplankton (terdiri dari beberapa marga) adalah makanan utama teripang, dengan indek preponderasi lebih dari 50\%. Hasil analisis isi perut teripang disajikan pada Gambar 2 dan 3, dan Tabel 3-14 (Lampiran).
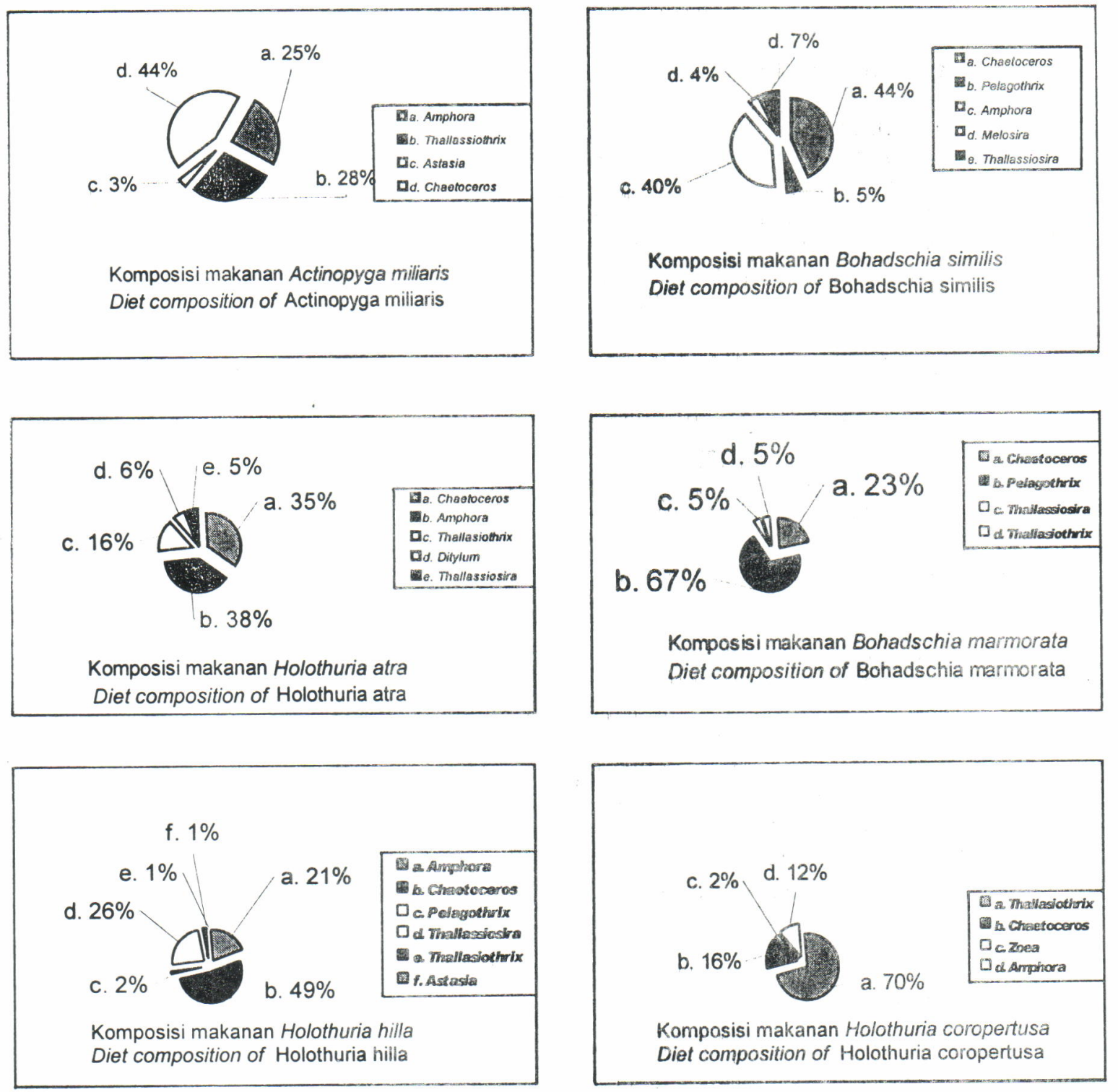

Gambar 2. Komposisi makanan pada beberapa jenis teripang

Figure 2. Diet composition of some sea cucumbers 

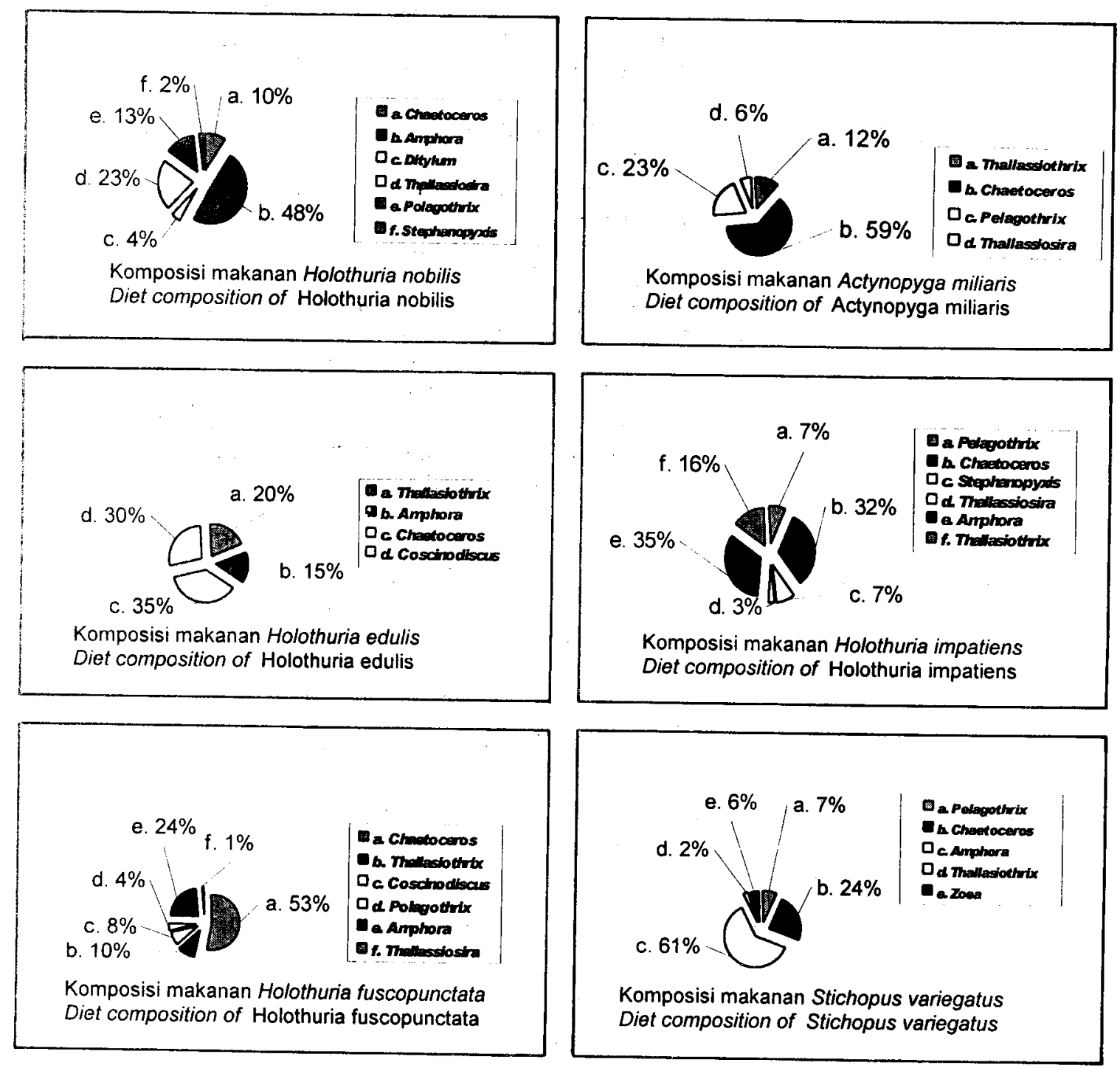

Gambar 3. Komposisi jenis makanan pada beberapa jenis teripang

Figure 3. Diet composition of some sea cucumbers

Pengamatan pada isi perut Actinopyga miliaris menunjukkan bahwa butiran pasir mendominasi dengan volume sebesar $90 \%$. Butiran pasir yang merupakan bagian dari substrat perairan adalah tempat menempel plankton dan detritus yang dimakan oleh teripang dengan menggunakan tentakelnya dan kemudian dikeluarkan kembali melaiui anusnya. Dengan demikian pasir bukanlah makanan utama akan tetapi hanya sebagai alat bantu untuk memperoleh plankton dan detritus. Makenan utamanya adalah Chaetoceros sp, salah satu marga dari fitoplankton yang mempunyai indek preponderasi paling tinggi yaitu sebesar $40 \%$. Demikiaan juga hasil pengamatan pada teripang Bohadschia similis, Holothuria edulis, Holothuria hilia, dan Holothuria fuscopunctata, makanan utamanya adalah Chaetoceros $\mathrm{sp}$ dengan indek propedensi antara $35-53 \%$.
Pengamatan pada isi perut Bohadschia marmorata, Pelagothrix yaitu salah satu marga dari fitolankton mempunyai nilai indek preponderasi $67 \%$. Pada isi perut Holothuria atra, indek preponderasi tertinggi adalah Amphora $38 \%$, juga merupakan salah satu marga dari fitoplankton. Pengamatan pada isi perut Holothuria hilla, indek preponderasi tertinggi adalah Chaetoceros $49 \%$. Pengamatan pada isi perut teripang Holothuria coronopertusa, Thallassiothrix juga merupakan salah satu marga dari fitoplankton mempunyai nilai indek preponderasi $70 \%$. Pengamatan pada isi perut Holothuria edulis, indek preponderasi tertinggi adalah Chaetoceros, sebesar $35 \%$.

Pengamatan pada isi perut Bohadschia similis menunjukkan bahwa makanan utamanya juga Chaetoceros dengan indek preponderasi $44 \%$. 
Pengamatan pada isi perut Bohadschia marmorata, Pelagothrix yaitu salah satu marga dari fitolankton mempunyai nilai indek preponderasi $67 \%$. Pada isi perut Holothuria atra, indek preponderasi tertinggi adalah Amphora 38\%, juga merupakan salah satu marga dari fitoplankton. Pengamatan pada isi perut Holothuria hilla, indek preponderasi tertinggi adalah Chaetoceros $49 \%$. Pengamatan pada isi perut teripang Holothuria coronopertusa, Thallassiothrix juga merupakan salah satu marga dari fitoplankton mempunyai nilai indek preponderasi $70 \%$. Pengamatan pada isi perut Holothuria edulis, indek preponderasi tertinggi adalah Chaetoceros, sebesar $35 \%$. Pengamatan pada isi perut Holothuria fuscopunctata, Chaetoceros mempunyai indek

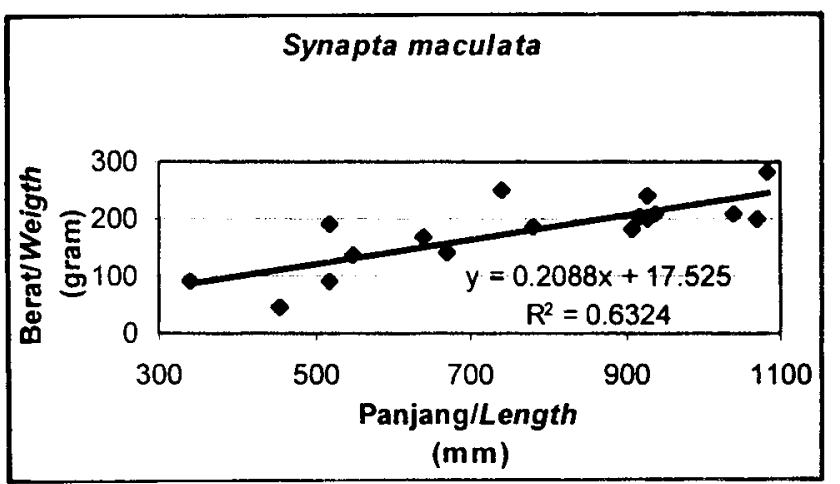

preponderasi $53 \%$. Pengamatan pada isi perut Holothuria impatiens, indeks preponderasi tertinggi adalah Amphora 35\%. Pengamatan pada isi perut Holothuria nobilis, indek preponderasi tertinggi adalah Amphora 48\%. Pengamatan pada isi perut Stichopus variegatus, indek preponderasi tertinggi adalah Amphora $61 \%$. Pengamatan pada isi perut Synapta maculata, Amphora mempunyai indek preponderasi tertinggi yaitu sebesar $68 \%$. Chaetoceros dan Amphora mendominasi isi perut sebagian besar teripang yang diamati. $\mathrm{Hal}$ ini kelihatannya terkait dengan dominasi jenis kelimpahan fitoplankton di suatu perairan. Hasil pengamatan kelimpahan fitoplankton di perairan Pulau Tikus dan Pulau Pramuka didominasi oleh marga Chaetoceros dan Amphora (Tabel 16 dalam Lampiran).

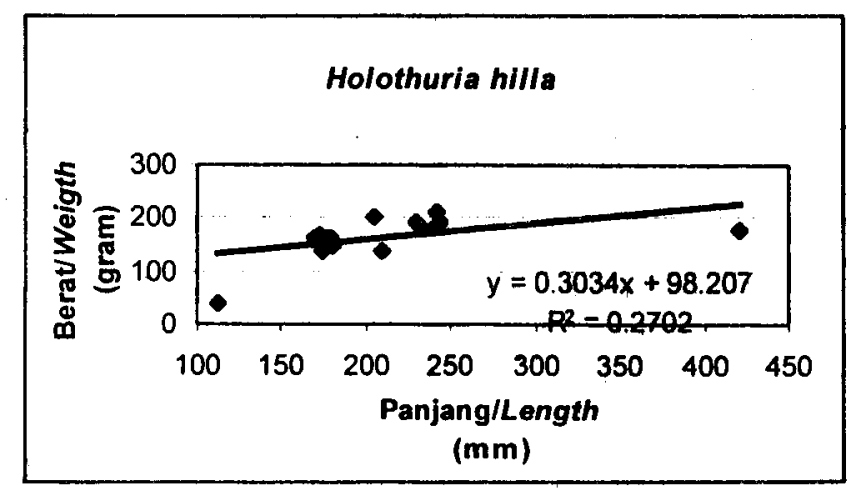

Gambar 4. Hubungan panjang dan bobot teripang di perairan Kepulauan Seribu. Figure 4. Length weight relationship of sea cucumber in Seribu Islands

\section{Pertumbuhan}

Hasil analisis hubungan panjang dan bobot tubuh teripang Synapta maculata, Holothuria hilla, dan Stichopus variegatus di perairan Pulau Tikus dan Pulau Pramuka, Kepulauan Seribu, diperoleh nilai b lebih kecil dari 3 . Hal ini berarti bahwa pertambahan panjang tubuh teripang tersebut tidak seimbang dengan pertambahan bobot tubuhnya. Pertumbuhan yang demikian adalah allometrik. Nilai b dihubungkan dengan koefisien pertumbuhan teripang, yaitu jika nilai $b$ lebih kecil dari 3 menunjukkan keadaan yang kurus di mana pertambahan panjang tubuh lebih cepat dari 
pertambahan bobot tubuhnya. Bilamana nilai $b$ lebih besar dari 3 menunjukkan keadaan yang montok di mana pertambahan bobot tubuh lebih cepat dari pertambahan panjang tubuhnya (Effendie, 1977). Hasil analisis hubungan panjang dan bobot teripang di perairan Kepulauan Seribu ini sama dengan hasil penelitian Tuwo (1996) pada Holothuria forskali di perairan Pulau Penfret, Perancis ; Andamari et al., (1988) pada Hiscabra, $H$. marmorata dan $H$. nobilis di pantai Kulur, Saparua ; Bonham dan Held (1963) pada $H$. atra dan $H$. leucospilota di Rongelap Atoll, Marshall Islands dan Rohani (1998) pada H. scabra di perairan Pulau Saugi, Kepulauan Spermonde, Sulawesi Selatan. Grafik hubungan panjang dan bobot teripang di perairan Kepulauan Seribu disajikan pada Gambar 4.

\section{KESIMPULAN}

1. Berdasarkan anatisis tingkat kematangan gonad dapat diduga bahwa musim pemijahan teripang di perairan Kepulauan Seribu berlangsung pada musim barat (DesemberFebruari).

2. Fitoplankton adalah makanan utama teripang, dengan indek preponderasi lebih dari $50 \%$.

3. Teripang di perairan Kepulauan Seribu pada umumnya mempunyai pola pertumbuhan allometrik negatif, yaitu menunjukkan keadaan yang kurus dimana pertambahara panjang lebih cepat dari pertambą̧a bobotnya.

\section{DAFTAR PUSTAKA}

Alwi, W. 1995. Beberapa Aspek Biologi Reproduksi dan Kualitas Habitat Teripang Pasir (Holothuria Scabra Jaeger) Ekonomis yang Dieksploitasi di Perairan Teluk Lampung. Fakultas Perikanan. Institut Pertanian Bogor. Bogor.

Andamari, R., T. Zubaidi, dan H. Banjar, 1988. Beberapa Catatan tentang. Teripang Pantai Kulur, Saparua. J. Penel. Perik. Laut (45) 6.49 57.

Azis, A. 1999. Status Penelitian Teripang Komersial di Indonesia. Prosiding Seminar tentang Oseanologi dan IImu Lingkungan Laut. Puslitbang Oseanologi. LIPI. Jakarta. Hal. 221232.

Bonham, K. and E. E. Held, 1963. Ecological Observations on the Sea Cucumbers Holothuria atra and $H$. leucospilota at Rongelap Atoll, Marshall Islands. Pasific Science XVII : 305314.

Effendie, M.I. 1997. Biologi Perikanan. Yayasan Pustaka Nusantara. Yogyakarta.163 hal.

Hyman, 1955. The Invertebrates. Echinodermata, the Coelomata Bilateria, Mc Graw Hill Co. Inc. New York. Vol/IV. Hal 121.

Jiaxin, C. 1990. Brief Introduction to Mariculture of Five Selected Species in China. In. Regional Seafarming Development and Demonstration Project. Bangkok, Thailand. P. 10-31.

Misnawati, H. 1997. Pembenihan Teripang Pasir (Holothuria Scabra Jaeger) di Balai Budi Daya Air Payau Jepara, Jawa Tengah. Fakultas Perikanan. Institut pertanian Bogor. Bogor.

Lawrence, J.M. 1987. A Functional Biology of Echinoderms. The John Hopkins University Press. Baltimore, Maryland. $340 \mathrm{p}$.

Rohani, A.R. 1998. Sebaran Ukuran dan Kematangan Gonad Teripang Pasir (Holothuria Scabra, Jaeger) pada Berbagai Kedalaman Perairan. Program Pasacasarjana. Institut Pertanian Bogor.

Rupert, E.E. and R.D. Barnes, 1994. Invertebrates Zoology. Sixth Edition. Saunders Colleges Publishing. Philadelphia. 1056 p.

Storer, T.I., R.C. Stebbins, R.L. Usinger, dan J.W. Nybakken, 1979. General Zoology. Sixth Edition. McGraw-Hill Inc. New York. 902 p.

Tuwo, A. 1996. Pertumbuhan dan Mortalitas Teripang Jenis Holothuria forskali di Perairan Pulau Penfret, Perancis, Buletin IImu Kelautan, Torani 1 (6) : 9-17. 
Sri Tumi Hartati, Suprapto, Indar Sriwahyuni, dan Rusmawati Zainy

LAMPIRAN

Appendix

Tabel 3. Kandungan isi perut Actynopyga miliaris

Table 3. Diet content of Actynopyga miliaris

\begin{tabular}{lcccc}
\hline Jenis Makanan & $\begin{array}{c}\text { Frekwensi Kejadian } \\
\text { (Fk) (\%) }\end{array}$ & $\begin{array}{c}\text { \% Volume } \\
\text { Penutupan }\end{array}$ & $\begin{array}{c}\text { In } \\
\text { Pof }\end{array}$ & $\begin{array}{c}\text { Index of } \\
\text { Preponderance (\%) }\end{array}$ \\
\hline Pasir & 100 & 90 & - & \\
Amphora & 100 & 0.9 & 90 & 25.00 \\
Thallasiothrix & 100 & 1.0 & 100 & 28.00 \\
Astasia & 100 & 0.1 & 10 & 3 \\
Chaetoceros & 100 & 1.6 & 160 & 44.44 \\
\hline
\end{tabular}

Tabel 4. Kandungan isi perut Bohadshia similis

Table 4. Diet Content of Bohadshia similis

\begin{tabular}{lcccc}
\hline Jenis Makanan & $\begin{array}{c}\text { Frekwengi Kejadian } \\
(\text { Fk) }(\%)\end{array}$ & $\begin{array}{c}\text { \% Volume } \\
\text { Penutupan }\end{array}$ & $\begin{array}{c}\text { Index of } \\
\text { P }\end{array}$ & $\begin{array}{c}\text { Preponderance (\%) } \\
\text { Pasir }\end{array}$ \\
\hline & 100 & 62.75 & - & - \\
Chaetoceros & 100 & 9.45 & 945 & 44 \\
Pelagothrix & 100 & 1.15 & 115 & 5 \\
Amphora & 100 & 8.7 & 870 & 40 \\
Melosira & 50 & 1.8 & 90 & 4 \\
Thallasiosira & 50 & 3.0 & 150 & 7 \\
\hline
\end{tabular}

Tabel 5. Kandungan isi perut Bohedschia marmorata

Table 5. Diet Content of Bohedschia marmorata

\begin{tabular}{lcccc}
\hline Jenis Makanan & $\begin{array}{c}\text { Frekwensi Kejadian } \\
\text { (Fk) }(\%)\end{array}$ & $\begin{array}{c}\text { \% Volume } \\
\text { Penutupan }\end{array}$ & $\begin{array}{c}\text { Index of } \\
\text { Pogenderance (\%) }\end{array}$ \\
\hline Pasir & 100 & 93.0 & - & - \\
Chaetoceros & 100 & 0.5 & 50 & 23 \\
Pelagothrix & 100 & 1.5 & 150 & 67 \\
Thallasiosira & 100 & 0.1 & 10 & 5 \\
thallasiothrix & 100 & 0.1 & 10 & 5 \\
\hline
\end{tabular}

Tabel 6. Kandungan isi perut Holothuria atra

Table 6. Diet Content of Holothuria atra

\begin{tabular}{lcccc}
\hline Jenis Makanan & $\begin{array}{c}\text { Frekwensi Kejadian } \\
\text { (Fk) }(\%)\end{array}$ & $\begin{array}{c}\text { \% Volum } \\
\text { Penutupan }\end{array}$ & $\begin{array}{c}\text { Index of } \\
\text { Prose }\end{array}$ & $\begin{array}{c}\text { Inder } \\
\text { Proponderance (\%) }\end{array}$ \\
\hline Pasir & 100 & 89.0 & - & - \\
Chaetoceros & 100 & 2.6 & 260 & 35 \\
Amphora & 100 & 2.8 & 280 & 38 \\
Thallasiothrix & 100 & 1.2 & 120 & 16 \\
Ditylum & 100 & 0.5 & 50 & 6 \\
Thallasiosira & 100 & 0.4 & 40 & 5 \\
\hline
\end{tabular}


Tabel 7. Kandungan isi perut Holothuria hilla

Table 7. Diet Content of Holothuria hilla

\begin{tabular}{lcccc}
\hline Jenis Makanan & $\begin{array}{c}\text { Frekwensi Kejadian } \\
(\mathbf{F k})(\%)\end{array}$ & $\begin{array}{c}\text { \% Volume } \\
\text { Penutupan (Vi) }\end{array}$ & Fk x Vi & $\begin{array}{c}\text { Index of } \\
\text { Preponderance (\%) }\end{array}$ \\
\hline Pasir & 100 & 86.53 & - & - \\
Amphora & 100 & 1.05 & 105 & 21 \\
Chaetoceros & 100 & 2.5 & 250 & 49 \\
Pelagothrix & 50 & 0.17 & 8.5 & 2 \\
Thallasiosira & 83.33 & 1.58 & 131.66 & 26 \\
Thallasiothrix & 33.33 & 0.3 & 6.66 & 1 \\
Astasia & 16.67 & 0.2 & 3.33 & 1 \\
\hline
\end{tabular}

Tabel 8. Kandungan isi perut Holothuria coronopertusa

Table 8. Diet Content of Holothuria coronopertusa

\begin{tabular}{lcccc}
\hline Jenis Makanan & $\begin{array}{c}\text { Frekwensi Kejadian } \\
\text { (Fk) (\%) }\end{array}$ & $\begin{array}{c}\text { \% Volume } \\
\text { Penutupan (Vi) }\end{array}$ & Fk x Vi & $\begin{array}{c}\text { Index of } \\
\text { Preponderance (\%) }\end{array}$ \\
\hline Pasir & 100 & 90 & - & \\
Thallasiothrix & 100 & 6.7 & 670 & 70 \\
Chaetoceros & 100 & 1.5 & 150 & 16 \\
Zoea & 100 & 0.2 & 20 & 2 \\
Amphora & 100 & 1.15 & 115 & 12 \\
\hline
\end{tabular}

Tabel 9. Kandungan isi perut Holothuria edulis

Table 9. Diet Content of Holothuria edulis

\begin{tabular}{lcccc}
\hline Jenis Makanan & $\begin{array}{c}\text { Frekwensi Kejadian } \\
\text { (Fk) (\%) }\end{array}$ & $\begin{array}{c}\text { \% Volume } \\
\text { Penutupan (Vi) }\end{array}$ & Fk X Vi & $\begin{array}{c}\text { Index of } \\
\text { Preponderance (\%) }\end{array}$ \\
\hline Pasir & 100 & 94.5 & - & - \\
Thallasiothrix & 100 & 0.4 & 40 & 20 \\
Amphora & 100 & 0.3 & 30 & 15 \\
Chaetoceros & 100 & 0.7 & 70 & 35 \\
Coscinodiscus & 100 & 0.6 & 60 & 30 \\
\hline
\end{tabular}

Tabel 10. Kandungan isi perut Holothuria fuscopunctata

Table 10. Diet Content of Holothuria fuscopunctata

\begin{tabular}{lcccc}
\hline Jenis Makanan & $\begin{array}{c}\text { Frekwensi Kejadian } \\
\text { (Fk) (\%) }\end{array}$ & $\begin{array}{c}\text { \% Volume } \\
\text { Penutupan (Vi) }\end{array}$ & Fk x Vi & $\begin{array}{c}\text { Index of } \\
\text { Preponderance (\%) }\end{array}$ \\
\hline Pasir & 100 & 69.0 & - & - \\
Chaetoceros & 100 & 5.3 & 530 & 53 \\
Thallasiothrix & 100 & 1.03 & 103 & 10 \\
Coscinodiscus & 100 & 0.77 & 77 & 8 \\
Pelagothrix & 100 & 0.37 & 37 & 4 \\
Amphora & 100 & 2.43 & 243 & 24 \\
Thallasiosira & 100 & 0.15 & 15 & 1 \\
\hline
\end{tabular}


Tabel 11. Kandungan isi perut Holothuria impatiens

Table 11. Diet Content of Holothuria impatients

\begin{tabular}{lcccc}
\hline Jenis Makanan & $\begin{array}{c}\text { Frekwensi Kejadian } \\
(\text { Fk) }(\%)\end{array}$ & $\begin{array}{c}\text { \% Volume } \\
\text { Penutupan (Vi) }\end{array}$ & Fk x Vi & $\begin{array}{c}\text { Index of } \\
\text { Preponderance (\%) }\end{array}$ \\
\hline Pasir & 100 & 90.75 & - & - \\
Pelagothrix & 100 & 0.25 & 25 & 7 \\
Chaetoceros & 100 & 1.1 & 110 & 32 \\
Stephanopyxis & 100 & 0.25 & 25 & 7 \\
Thallasiosira & 100 & 0.1 & 10 & 3 \\
Amphora & 100 & 1.15 & 115 & 35 \\
Thallasiothrix & 50 & 1.1 & 55 & 16 \\
\hline
\end{tabular}

Tabel 12. Kandungan isi perut Holothuria nobilis

Table 12. Diet Content of Holothuria nobilis

\begin{tabular}{lcccc}
\hline Jenis Makanan & $\begin{array}{c}\text { Frokwensi Kejadian } \\
(\text { FK) }(\%)\end{array}$ & $\begin{array}{c}\text { \% Volume } \\
\text { Penutupan (Vi) }\end{array}$ & Fk $\times$ Vi & $\begin{array}{c}\text { Index of } \\
\text { Preponderance (\%) }\end{array}$ \\
\hline Pasir & 100 & 94.25 & - & - \\
Chaetoceros & 100 & 0.25 & 25 & 10 \\
Amphora & 100 & 1.25 & 125 & 48 \\
Ditylum & 50 & 0.20 & 10 & 4 \\
Thallasiosira & 100 & 0.60 & 60 & 23 \\
Pelagothrix & 50 & 0.70 & 35 & 13 \\
Stephanopyxis & 50 & 0.10 & 5 & 2 \\
\hline
\end{tabular}

Tabel 13. Kandungan isi perut Stichopus variegatus

Table 13. Diet Content of Stichopus variegatus

\begin{tabular}{lcccc}
\hline Jenis Makanan & $\begin{array}{c}\text { Frekwensi Kejadian } \\
(\text { Fk) }(\%)\end{array}$ & $\begin{array}{c}\text { \% Volume } \\
\text { Penutupan (Vi) }\end{array}$ & Fk X Vi & $\begin{array}{c}\text { Index of } \\
\text { Preponderance (\%) }\end{array}$ \\
\hline Pasir & 100 & 87.83 & - & - \\
Pelagothrix & 66.67 & 0.4 & 26.68 & 7 \\
Chaetoceros & 100 & 0.87 & 87 & 24 \\
Amphora & 100 & 2.23 & 223 & 61 \\
Thallasiothrix & 66.67 & 0.65 & 65 & 2 \\
Zoea & 33.33 & 0.20 & 20 & 6 \\
\hline
\end{tabular}

Tabel 14. Kandungan isi perut Synapta maculata

Table 14. Diet Content of Synapta maculata

\begin{tabular}{lcccc}
\hline Jenis Makanan & $\begin{array}{c}\text { Frekwensi Kejadian } \\
\text { (Fk) }(\%)\end{array}$ & $\begin{array}{c}\text { \% Volume } \\
\text { Penutupan (Vi) }\end{array}$ & Fk x Vi & $\begin{array}{c}\text { Index of } \\
\text { Preponderance (\%) }\end{array}$ \\
\hline Pasir & 100 & 77.00 & 7 & - \\
Zoea & 66.67 & 0.50 & 33.33 & 4 \\
Amphora & 100 & 6.03 & 603 & 68 \\
Chaetoceros & 100 & 1.67 & 167 & 19 \\
Pelagothrix & 66.67 & 0.30 & 20 & 2 \\
Ditylum & 66.67 & 0.20 & 13.33 & 2 \\
Trichodesmium & 33.33 & 0.50 & 16.67 & 2 \\
Melosira & 33.33 & 0.30 & 9.99 & 1 \\
Thallassiosira & 33.33 & 0.50 & 16.67 & 2 \\
\hline
\end{tabular}


Tabel 16. Rata-rata kelimpahan fitoplankton $\left(\mathrm{sel} / \mathrm{m}^{3}\right.$ ) dan zooplankton (ind $/ \mathrm{m}^{3}$ ) di perairan Kepulauan Seribu.

Table 16. The averages of phytoplankton $\left(c e l l / \mathrm{m}^{3}\right)$ and zooplankton (ind/ $\left.\mathrm{m}^{3}\right)$ abundance in Seribu Island Waters

\begin{tabular}{clcc}
\hline No. & $\begin{array}{c}\text { Jenis Plankton } \\
\text { (Kinds of plankton) }\end{array}$ & $\begin{array}{c}\text { Pulau Tikus } \\
\text { (Tikus Island) }\end{array}$ & $\begin{array}{c}\text { Pulau Pramuka } \\
\text { (Pramuka Island) }\end{array}$ \\
\hline Fitoplankton/Phytoplankton & & 12.290 \\
\hline 1 & Amphora & 10.600 & 3.180 \\
2 & Astasia & 3.000 & 16.930 \\
3 & Chactoceros & 19.340 & 2.770 \\
4 & Coscinodiscus & 3.110 & 2.260 \\
5 & Ceratium & 2.270 & 3.070 \\
6 & Coscinosira & 2.920 & 2.850 \\
7 & Coelosphacrium & - & 3.110 \\
8 & Dinophysis & - & 5.050 \\
9 & Ditylum & 2.110 & 2.070 \\
10 & Holopodium & - & 2.050 \\
11 & Melosira & 3.810 & 2.020 \\
12 & Merismopedia & - & 2.040 \\
13 & Navicula & 4.200 & 3.010 \\
14 & Nitzschia & - & 2.470 \\
15 & Oscillatoria & 2.780 & 3.100 \\
16 & Pleurosigma & 2.610 & 5.710 \\
17 & Pelagothrix & 3.350 & 3.410 \\
18 & Pyrocystis & 2.740 & 4.130 \\
19 & Rhizosolenia & - & - \\
20 & Schoderella & 2.720 & 5.200 \\
21 & Stephanopyxis & 2.520 & 3.210 \\
22 & Thallasiosira & 2.880 & 3.070 \\
23 & Thallasiothrix & 4.200 & 3.820 \\
24 & Trichodesmium & 2.160 & $\mathbf{9 6 . 8 2 0}$ \\
\hline
\end{tabular}


Tabel 15. Kisaran dan rata-rata panjang dan bobot beberapa jenis teripang di perairan Kepulauan Seribu

Table 15. Ranges and avarages of length and weight of several kind of sea cucumbers in the waters of Seribu Islands

\begin{tabular}{clcc}
\hline No. & \multicolumn{1}{c}{$\begin{array}{c}\text { Jenis teripang } \\
\text { (Species of cucumber) }\end{array}$} & $\begin{array}{c}\text { Panjang (mm) } \\
(\text { Length) }\end{array}$ & $\begin{array}{c}\text { Bobot (gram) } \\
\text { (Weight) }\end{array}$ \\
\hline 1 & Synapta maculata & $340-1.083$ & $45-280$ \\
& & $(766)$ & $(178)$ \\
2 & Stichopus variegatus & $239-350$ & $525-780$ \\
& Holothuria impatien & $(290)$ & $(701)$ \\
& & $130-230$ & $45-180$ \\
4 & Bohadschia marmorata & $(195)$ & $(115)$ \\
& & $160-270$ & $100-220$ \\
5 & Holothuria hilla & $(220)$ & $(148)$ \\
& & $112-420$ & $40-210$ \\
6 & Actinopyga miliaris & $(212)$ & $(163)$ \\
7 & Bohadschia similis & 115 & 40 \\
& & $165-192$ & $160-250$ \\
9 & Holothuria atra & $(179)$ & $(205)$ \\
9 & Holothuria coronopertusa & 160 & 305 \\
& & $190-447$ & $120-680$ \\
10 & Holothuria fuscopunctata & $(319)$ & $(400)$ \\
& & $156-184$ & $100-140$ \\
11 & Holothuria edulis & $(167)$ & $(118)$ \\
& & $105-290$ & $(210)$ \\
12 & Holothuria nobilis & $(197)$ & $190-380$ \\
& & $180-230$ & $(285)$ \\
\hline
\end{tabular}

